PART TWO

\title{
The Divo, or the Governance of Romance
}





\section{4 \\ The Divo, New-Style Heavy}

You know producers can't make stars. The public makes stars. You can't make a star by writing the name on a lot of advertising. [. . .] Nobody can make stars of nothing.

ADELA ROGERS ST. JOHNS, PHOTOPLAY, $1922^{1}$

\section{TRANSNATIONAL AMERICA}

During the first years of the twentieth century, the American film industry was compelled to produce films of clear national significance capable of prevailing over foreign films' competition. Richard Abel has described this process as the "Americanization of American cinema." this phenomenon but also introduced, at least in highbrow intellectual circles, an opposing, post-melting-pot formulation of Americanism. As we saw in chapter 2, from the mid-1910s onward, progressive intellectuals like Kallen, Bourne, and James came to acknowledge America's constitutive openness to transnational influences. This notion eventually moved from the lofty pages of highbrow periodicals to more popular ones. By the war's end, film journals had begun to recognize the critical role that America's national diversity played in U.S. films' propaganda effectiveness. In 1918 Louella Parsons argued that America's "cosmopolitan population of mixed races" was what enabled Hollywood to "reach the very people Germany is struggling to get into its clutches."3 Similarly, film periodicals praised both the seamlessness with which foreign immigrants become American film spectators and American film culture's inclusion of foreign characters and representations. In a 1921 Photoplay article entitled "Making Americans by Movies," Max Watson argued that the Americanizing process did not start at Ellis Island, where educational films were shown, but abroad where would-be immigrants first learned about America before embarking on their long journey. "Wherever one goes the world over," he wrote, "[the traveler] finds the American movie, for ninety per cent of the motion pictures of the world are American."4 The flip side of Watson's proud statement was something that his own periodical had been covering for some time: the multinational openness of film culture. In an illustrated, full-page editorial in 1918 entitled "The Melting Pot" and devoted to 
Isaac Zangwill's famous play from a decade earlier, Photoplay published a remarkable polemical plea:

Zangwill's vision is to today's actuality as an assayer's flame to a blast furnace. In the roaring converter of war more than nations are fusing. [.. . ] The Iowa lad is learning that the French aren't frog-eaters, nor are the Italians "Ginnies."

Five years later, Motion Picture Classic identified American cinema's fondness for foreign settings and characters, particularly European ones, as an index of a widespread inclination unknown a few years earlier. The article compared the phenomenon to nothing less than a psychological fixation:

Hollywood is undergoing a European complex. Nearly every production now filming, or in immediate prospect, has a foreign setting. Witness: "Ben Hur," [. . . "The Hunchback of Notre Dame," "Scaramouche." [. . . The scene of every one of these plays is laid abroad. ${ }^{6}$

While the discursive emergence of a transnational and cosmopolitan America did not defeat anti-immigration policies in Congress, it contributed to spreading a notion of cultural pluralism that permitted popular appreciation of foreign personalities. Still, how could two foreigners be made into national celebrities? How could any embrace of foreign masculinity be made not just possible but also desirable?

\section{COSMOPOLITAN MASCULINITY AND ITALIANNESS}

In Manliness and Civilization: A Cultural History of Gender and Race in the United States, 1880-1917, Gail Bederman offers one of the most articulate contributions to the history of turn-of-the-century American manhood. First, she clarifies the terms of the question. She names manliness as the idealized notion of male identity that since the early nineteenth century had pervaded American society. Its chief traits were "moral character, high-minded self-restraint, and virtuous self-mastery." For over a century, she argues, manliness represented the source of middleclass men's authority over women and the lower classes. ${ }^{7}$ By the 1890 , however, manliness and middle-class identity were noticeably faltering. The causes were diverse: economic crisis and a prolonged post-1893 depression, related to largescale capitalist competition; greater demand for urban clerical jobs in large, anonymous corporations; increased gender and racial diversity in the labor force; movements for women's suffrage; immigrants' left-leaning political engagement; and the expanded role of consumer culture in shaping class and gender identities. ${ }^{8}$ Different causes but, in Bederman's analysis, a convergent result: ideas and practices of racial distinction were used to recast ideas and practices of manhood. "As white middle-class men actively worked to reinforce male power," she argues, "their race became a factor which was crucial to their gender." A novel attention to corporeal features, particularly regarding race, became pivotal to middle-class 
white men's attempt to remake manhood in order to sustain their cultural and political power. European immigrants and working-class men provided useful examples. The popularity of saloons and music halls, with their displays of plebeian muscular virility, led to a reformulation of Victorian manliness through the adoption of a cult of strenuous life that translated into physical prowess, pugnacity, and sexuality. Taking decades to unfold, this trajectory from idealized to corporeal manhood, or masculinity, produced several iconic characters, popular practices, and institutions, including the widely admired Prussian muscleman Eugene Sandow, Theodore Roosevelt's Rough Riders, and the growing popularity of college football and YMCA. According to Bederman, this complex recasting was rooted in the invocation of a notion of civilization that while seeking to balance nature and culture, served to relegitimize hierarchies of race, gender, and class.

The broad tension between civilization and primitivism resulted in two different outcomes. The first relied on opposition: imperialists and nativists maintained that only civilized white men possessed the racial genius for self-government, a status that implied the subjugation of primitive races-both at home and abroad. The second was one of appropriation. Against the risks of overcivilization and "neurasthenia," to use a contemporary term, ${ }^{10}$ the other option was to embrace the racially impure and plebeian notion of muscular physicality while simultaneously gentrifying it. Popular culture fostered this safe transformation and developed it on a grand scale.

Several major cultural events can be read in this light. The exceptional popularity of the 1910 fight between Jim Jeffries and Jack Johnson, which opposed "Protestant virtue" (and whiteness) against "uncivilized [black] savagery," managed to lift boxing to a defining arena of white men's male identity. Not despite but because of Jeffries's loss, the event signaled the embrace of physical force as a marker of new masculinity. Likewise, Edgar Rice Burroughs's widely successful Tarzan of the Apes, serialized in 1912 and published as a book in 1914, combined the best of two worlds: as the scion of British aristocracy who was lost and raised by apes, Tarzan effortlessly masters the laws of the jungle and displays a double primacy: a noble and civilized morality in an exuberant, primitive body. The inclusion of forceful (and sexual) physicality into the definition of gender identity was not to be an exclusively male affair, however. In 1913 Burroughs also serialized the adventures of a sensual "cavegirl," and the same cultural tenet reemerged in the 1922 best seller Caveman within Us. Primitivism came to hold a wide appeal for "civilized" white audiences.

Unleashing primal instincts could also be done with style. Growing attention to the body, in the context of the growing consumer culture, enhanced other forms of gendered identity that were rooted in physical strength or athletic ability as well as elegance, sexuality, and youth. This was a dynamic that brought together white men and women - the flapper and her lesser known boyfriend, the bacheloraround insistent consumer fantasies that challenged Victorian ideals of diligence, thrift, and self-control (for him), domesticity (for her), and selflessness (for both). ${ }^{11}$ If the flapper represented a new urban female figure, the bachelor had precedents 
in the "dude" of the nineteenth century (who was marginal and often ridiculed), as well as in the iconic British dandy and the Continental flâneur. At a time of soaring college enrollment, greater job opportunities in the cities, and a flourishing consumerism geared toward younger people with disposable income, unattached bachelors and uncommitted flappers fostered a peer-based, sensualized, and hedonistic youth culture. It centered on fashion and seduction strategies visible at dance halls, billiard parlors, and movie palaces. Even advertisements for men's clothing contributed to broadcast a "sporty and virile image in ordinary life that guaranteed stylishness but not at the cost of effeminacy." ${ }^{12}$

The heterosocial culture of this "flaming youth" came with new rules prompted by the development of exotic music and dances that were associated with different races and geographies. In nightclubs and public dance halls, jazz, the fox-trot, and especially the tango allowed for new casual rituals of courtship in an elegant atmosphere of risqué displays of youthful desire and exotic sex appeal. ${ }^{13}$ While soon to be accepted in America, one need only think of the flaunting sexual primitivism of Josephine Baker's famous banana dance that debuted in Paris in 1925. Not all primitivisms and not all alleged primitives, however, were acceptable. How would the new masculinity of the Divo and the Duce fare in relation to American racial dynamics of the 1920s? Their Italianness, after all, could have hindered as much as fostered their acceptance as American role models.

In American silent films, Italians had come to occupy a varied but not unlimited range of characterizations. Through the aesthetic and centuries-old prism of the picturesque, Italians' cultural foreignness and alleged anthropological dissonance had unfolded into two main types of appealing but othering representations. The first one insisted on their backwardness and domesticated primitivism, mostly through love melodramas of passionate jealousy and heartbreaking loss. The second one relied on a notion of innate criminality, unfolding in stories of impossible-to-romanticize violence. From 1915 on, however, the American stage and film actor George Beban had become the master impersonator of tragic but sympathetic Italian subjects capable of undergoing moral domestication amidst heartbreaking circumstances. In such feature-length immigrant dramas as The Italian (1915) and The Sign of the Rose (1915 and 1922), his performances enabled American audiences to develop an intense emotional solidarity-although not necessarily an identification - with heavily racialized white, foreign characters. ${ }^{14}$

Meanwhile, other narratives about Italian immigrants had begun to appear after Behan's rise to fame. Written by female screenwriters such as Sonya Levien, Anita Loos, Jeanie Macpherson, June Mathis, and Frances Marion, these dramas of transoceanic migration and tenement life did not reproduce Beban's safe trajectory of adaptation. They featured female protagonists, not male characters, engaged in passionate and controversial love stories that questioned conventional ideas of American morality and propriety. While presenting the departure from the Old World as a journey that severed oppressive traditional ties, titles like 
A Woman's Honor (1916), The Ordeal of Rosetta (1918), and Who Will Marry Me? (1919) explored questions of social freedom and personal sexual expression without any of Beban's noted moralism. ${ }^{15}$ Such daring narratives can be viewed as symptomatic of broader changes in American culture. At a minimum, though, they tell us about Hollywood as a powerful dynamo that created new character types and ideas of personal fulfillment that were not evident in the country's social and cultural landscape. As film periodicals boasted, "Motion-Picture Land" was an ideal living space filled with independence-seeking women of different backgrounds and uncommon talents. If the West had represented a virile space for many of Fairbanks's Rooseveltian characters, "the modern West's possession of Hollywood," as Hilary Hallett showed, "created perhaps the most powerful generator and lure for a New Western Woman in full flight from feminine norms." 16 The trope of democratic access, informed by a new sense of self-reinvention, identified Hollywood as not just a center of national and world film production but also a capital capable of modeling spectatorial experience and consumption. ${ }^{17}$ It may have been a dream factory, but "women's remarkable record of influence inside the movie colony of this era was no fantasy." 18

Against the stereotype of the "movie-struck girl", the growth of women's presence in early 1910 s Hollywood corresponded to the film industry's efforts to turn the boisterous and plebeian films into a profitable family-friendly entertainment. It was a move that enabled and then capitalized on the post-World War I emergence of American film and fan culture as women-oriented, given the prevailing gender of both moviegoers and screen magazine readers. The results were, however, not just conventional morality tales of family reunion and romantic love but also stories that pushed the boundaries of traditional female roles. ${ }^{19}$ Consider the film heroines of such serials as The Adventures of Kathlyn (1914), The Perils of Pauline (1914), and The Exploits of Elaine (1914). Centered on plucky female characters who prefer harrowing adventures to conventional family roles, the serial queen melodramas represented one of the first attempts by the film industry to cater to female patrons on a national scale. ${ }^{20}$ The culture of these films challenged the notion that increasing female film patronage went hand in hand with the industry's efforts to attain a higher moral respectability. "Serial content was anything but tame," Shelley Stamp argues, "and reports of audience behavior suggest that fans conducted themselves in anything but a 'respectable' manner." ${ }^{21}$

In the same period, women began to enter many areas of the film industry itself under the shared, though not enduring, assumption that women knew best how to cater to the female spectators. ${ }^{22}$ Even though women occupied several critical positions at the creative and management level, in no other field were women as powerful as in screenwriting. ${ }^{23}$ Women wrote "at least half of all silent films," were among the highest-paid and most-recognized screenwriters, and "were responsible for crafting many of the era's landmark screen personalities (Mary Pickford, Rudolph Valentino, Douglas Fairbanks, Clara Bow, and Gloria 
Swanson)." ${ }^{24}$ Women screenwriters made an impact on a number of genres, including the social-problem film and the historical epic, but they left their most recognizable mark in the creation of modern narratives about romance and marriage.

During and especially after the war, the expansion of work and consumption possibilities for young women created the material conditions that allowed many to envision equality in marriage and in romantic relationships. These changes did not exactly correspond to the aspirations of generations of suffragists culminating in the passing of the Nineteenth Amendment. As Frederick Lewis Allen perhaps too dismissively noted in his iconic Only Yesterday, "few of the younger women could rouse themselves to even a passing interest in politics." ${ }^{25}$ Still, Hollywood screenwriters embraced the novel civic arrangements and wrote scripts that explored new secularized forms of gender relationships that distanced themselves from traditional religious prescriptions. In the postwar context of an expanded suffrage and corporatizing Hollywood, the film industry turned women's search for emotional and sexual expression into a management strategy for consumer and ideological choices through, once again, the mediating power of the actor testimonial. Only this time, the daring reimagination of marriage and romance unfolded within a much tighter framework of promotion and consumption. Cecil B. DeMille's films in the late 1910 s and early 1920 s starring Gloria Swanson and largely written by Jeanie Macpherson walked a fine line between the new demands for equality, self-expression, and the appeal of consumerism. ${ }^{26}$ While mostly adopting a female perspective, Old Wives for New (1918), Don't Change Your Husband (1919), and Why Change Your Wife? (1920) commodified marriage by stressing the intrusion of trendsetting fashion and consumer taste into romantic relationships. In these star-centered films, to quote Lary May, "leisure became an egalitarian arena." ${ }^{27}$ Through the exemplary mediation of the star, Hollywood studios sought to bypass film audiences' segmentation by gender, class, and race (and their respective subcultures) by appealing to a broader, more democratic fascination for consumer goods. More accessible and less elitist, the democratization of aspirational luxury turned Los Angeles into a daring and flashy adversary of Paris as the new arbiter of national and international fashion.

Multitudes of female (and male) spectators were made to see stars as models for the commodified democratization of their lives. The pervasiveness of the star system, particularly through the promotional input of fan magazines, accompanied the same massive education and influence pursued by the advertising agencies. At the same time, the industry's rhetorical positioning of moviegoing as a democratic practice cast audiences' choice of favorite films or stars as a free and spontaneous exercise. Spectators' preferences rewarded personalities who appeared to possess character, charm, and sex appeal. Nothing allegedly was supposed to stand between stars and audience according to a logic of unfiltered access, reception, and pleasure. In reality, the process by which audiences identified their favorite stars was hardly as spontaneous and democratic as film magazines made it out to be. 
Populist and star-centered explanations helped to conceal the role of a whole host of intertextual mediators, including fan magazines, and public relations specialists who molded audiences' reactions and directed their preferences to this or that figure according to both traditional, tried-and-true tactics and new tricks.

The case study of Valentino helps us understand that, by enabling the commodified democratization of American women spectators' lives, stars did not have to be female themselves and did not have to be American. Still, they were required to be white. The Divo's association with the celebrated, century-old myth of the romantic and sensual Latin lover not only shielded him from association with the vulgar hordes of Southern Italian immigrants but also made his performances function as an exploration of female desire that his all-American male peers could not themselves replicate. ${ }^{28}$ This may explain why Valentino, particularly after achieving nationwide notoriety in 1921, was never cast in the role of a contemporary immigrant landing and striving in America. ${ }^{29}$ He was a Hollywood Italian, after all, not a New York one.

\section{NEW-STYLE HEAVY}

Because The Four Horsemen of the Apocalypse is customarily identified as the first relevant item of Valentino filmography, scholars have paid scant attention to what he did or what was known about him before March 1921. On closer inspection, this may not be prudent. The reputation Valentino developed in New York, particularly during a sensational high-society scandal, arguably functioned as a primacy intertext for the publicity discourse that informed both the design and reception of his early film characterizations. Usually mentioned only in passing, Valentino's pre-Four Horsemen career allows us to reconstruct his trajectory toward mainstream acceptability from his early characterizations as a slick, evil foreign deuteragonist, or "a new style heavy"-the category he used to describe himself under the name of Rodolfo Di Valentina in the 1918 Motion Picture Studio Directory (figure 8). ${ }^{30}$ Pre-1921 titles may help explain how the perception of a foreign actor who often impersonated charmingly exotic villains provided screenwriters the basis to design characters' possible moral conversion and allowed publicists to harness his scandalous charm.

In fact, scandal is where we ought to start. After arriving in New York from Italy in December 1913, Valentino sought to make use of his background in agronomic sciences, but his first serious job as gardener on a Long Island estate did not last. Following Italy's entry into the First World War in 1915, he even sought to enlist in the Italian army-an event that would appear in several of his (auto)biographical profiles-but was turned down for poor vision by the Italian Recruitment Bureau. Finally, he found a semblance of financial stability as a dancer for hire in New York's musical clubs, where he was known by his given name, Rodolfo Guglielmi. Starting a career as a "taxi dancer" did not immediately translate into film roles, 


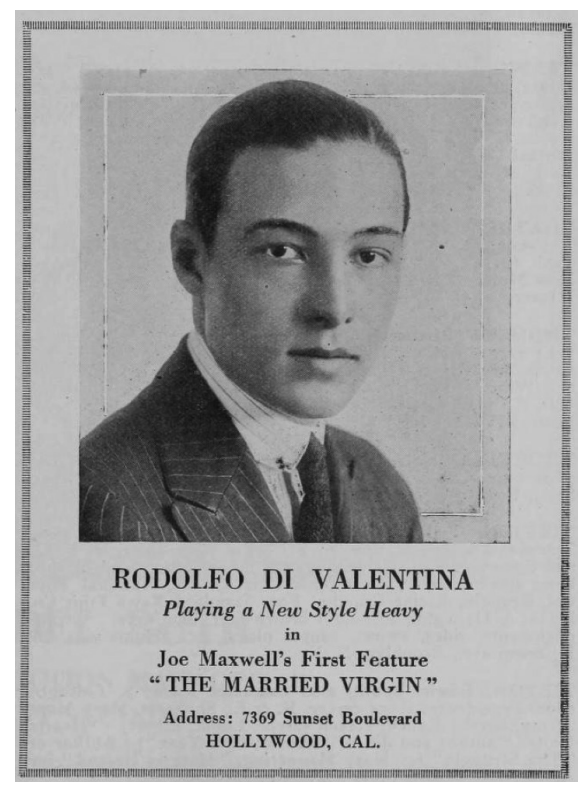

FIGURE 8. Rodolfo Di Valentina playing a "new style heavy." Motion Picture Studio Directory and Trade Annual (New York: Motion Picture News, 1918), 193.

save as a movie "dress extra" in New York film productions, but it gave him an opportunity to flaunt his talent as gifted dancer and seducer. ${ }^{31}$ Taxi dancing, in fact, was available for unchaperoned, well-off married women in search of a Continental-looking, fashionable young companion. Among the society women who gathered at the so-called tango temples, "dreading that they were going to be shocked, and fearing they were not," Valentino built a reputation as a typical "tango pirate." ${ }^{32}$ Yet, his life was not restricted to this potentially lurid trade. Hired by Broadway musical dancer Joan Sawyer in 1916 and touring with her on the Keith circuit, he even danced at a New York roadhouse for President Wilson. These gigs enabled him to meet actors who would later become friends and supporters, including Mae Murray and Norman Kerry.

In 1917, however, he hurriedly left New York following his turbulent involvement in legal proceedings that had dominated the gossip press throughout the previous year. He had agreed to serve as witness in the divorce case of a New York socialite, Bianca de Saulles, with whom he had been allegedly involved. His testimony attracted the vindictive ire of her powerful and soon-to-be former husband, Jack de Saulles. A friend of Wilson and cousin of a recent New York City mayor, Jack de Saulles was known to have strayed from the marriage much more often than his wife ever did. He arranged for Valentino to be arrested on the pretext of 
a white-slavery investigation in the home of a notorious madam who had been accused of blackmailing wealthy New Yorkers. The vice charges were ultimately dropped, and Valentino was released. Still, what has recently been described with retrospective hyperbole as the "Valentino affair" and the "Jazz Age murder scandal that shocked New York society and gripped the world" was not a minor public event. ${ }^{33}$ As many commentators later recounted, the press published disturbing (but inaccurate) accounts of his confession. For instance, the New York Tribune reported that he admitted being "a bogus count or marquis" but also added District Attorney Swann's description of Valentino as "a handsome man" who "wears corsets and a wristwatch" and "was often seen dancing in well-known hotels and tango parlors." ${ }^{34}$ As a homophobic insinuation about his masculinity, this coverage constituted a prolepsis of the infamous Chicago Tribune "Pink Powder Puffs" editorial that a few years later would provoke Valentino's fiery reaction. At the time Valentino did not yet have access to the powerful publicity enablers or friends who could have responded in kind to allegations against his masculinity or spun public opinion to his advantage. A minor figure on the fringes of polite society and mired in scandal, his best option was to leave town. Later that summer, Bianca de Saulles, unhappy about the custody agreement following her divorce, shot and killed her husband. The name Rodolfo Guglielmi resurfaced in the press. By then, he had fled to California.

The scandal followed him in ways that both threatened and shaped his career. His presumed association with white slavery, blackmail, and homosexuality left a persistent and unsavory mark on his reputation. Yet, even though several newspapers eventually issued retractions, the initial coverage's long-term impact was not entirely negative. ${ }^{35}$ Although it appears that the court records have remained sealed since 1917 and his arrest record mysteriously disappeared in the early 1920s, Valentino did not forget the infamy that the charges had brought him. "At the height of his fame, the world kissing his hand," publicist Herbert Howe wrote in a posthumous article, "he could not forget the three days he spent at the Tombs prison of New York on a false charge. [...] The retraction was small compared to the headlines that had damned him." ${ }^{36}$ If Valentino could not forget, neither did the publicity machine that ultimately surrounded him.

Initially, in order to escape from the coverage of the de Saulles scandal, Valentino moved to San Francisco. Mary Pickford was there for the production of The Little American, which had cast his friend Norman Kerry for a minor role. Encouraged by Kerry, Valentino made a few trips to Los Angeles to look for employment both in and out of the film business. ${ }^{37}$ His first Hollywood bit role was in Alimony (First National, 1917), written by Hayden Talbot, where he met another extra, Alice Terry, who would be his partner four years later in The Four Horsemen of the Apocalypse.

One of his earliest roles was that of a somewhat sympathetic character in The Married Virgin (Maxwell Productions, 1918), which was distributed only in 1920, 
both with its original title and the alternate one, Frivolous Wives. ${ }^{38}$ Directed by Joe Maxwell, the film was adapted for the screen by Hayden Talbot, the screenwriter of Alimony, from one of his own stories. While the original 1918 credits identify Valentino as "Rodolfo di Valentini" (with promotional material using "di Valentina" instead), later prints, including the restored one I examined, report his name as "Rudolph Valentino" in capital letters. The Married Virgin is a minor film, but the names of the conventional lovers, Doug and Mary, whose romance Valentino's character briefly but successfully threatens, are an obvious reference to Mary Pickford and Douglas Fairbanks. In 1918, while married to other spouses, they collaborated on several Liberty Bond drives, which fueled speculations of a destined affair. Valentino's hard-to-resist and intrusive erotic appeal in the lives of the fictional Doug and Mary is an emblematic prolepsis of his soon-to-be much publicized threat to conventional romantic scripts.

In The Married Virgin, Valentino plays the role of Count Roberto di San Fraccini, "an Italian nobleman and soldier of fortune," as one intertitle notes, who dresses impeccably in black, rides a black horse, and appears ambitious and morally unencumbered. His main occupation is as the illicit lover of a married woman, Mrs. Ethel McMillan. Obsessed with fashion, Count Roberto is a master of manners and seduction, as revealed by a lingering close-up of him gallantly kissing his older lover's hand (figure 9).

Upon learning from Ethel that a man is blackmailing her husband, a wealthy political operator, Roberto plots a criminal and financial scheme. The blackmailer claims that he can produce a revolver that Mr. McMillan had used to kill an enemy many years back. The count first plans to interject himself in the deal by also blackmailing Ethel's husband in exchange for the infamous gun (which he does not possess) and eloping with her. After the plan fails, he proposes an alternative to Ethel: he will marry her stepdaughter, Mary, to secure her dowry before escaping with Ethel to South America. The problem is that Mary is engaged to Douglas, a young lawyer, and the two of them form an apparently inseparable all-American couple. Roberto disrupts their idyllic love of romantic rides on their white horses with his sinister and opportunistic charm. He pays Mary a visit while she is spending time at a seaside resort without her fiancé. While the film should depict his scheming attempts at seducing Mary as utterly disagreeable, it instead lingers on his Old World gallantry and athletic skills. The unexpected intimacy between Roberto and Mary, evident in intense conversations and playful morning swims, grows intense, while his professional ambitions keep Douglas busy and distant. Although in her letters Mary reassures him about her loyalty, her prose notably does not hide her admiration for the mischievous Italian nobleman ("the most wonderful athlete I ever saw"). But soon Roberto reveals his calculating nature. He proposes marriage to a shocked Mary "with all the confidence a hundred conquests inspire" and later self-assuredly explains to her father that the "wedding is self-protection" and that "there shall be-a marriage settlement" (emphasis in the 


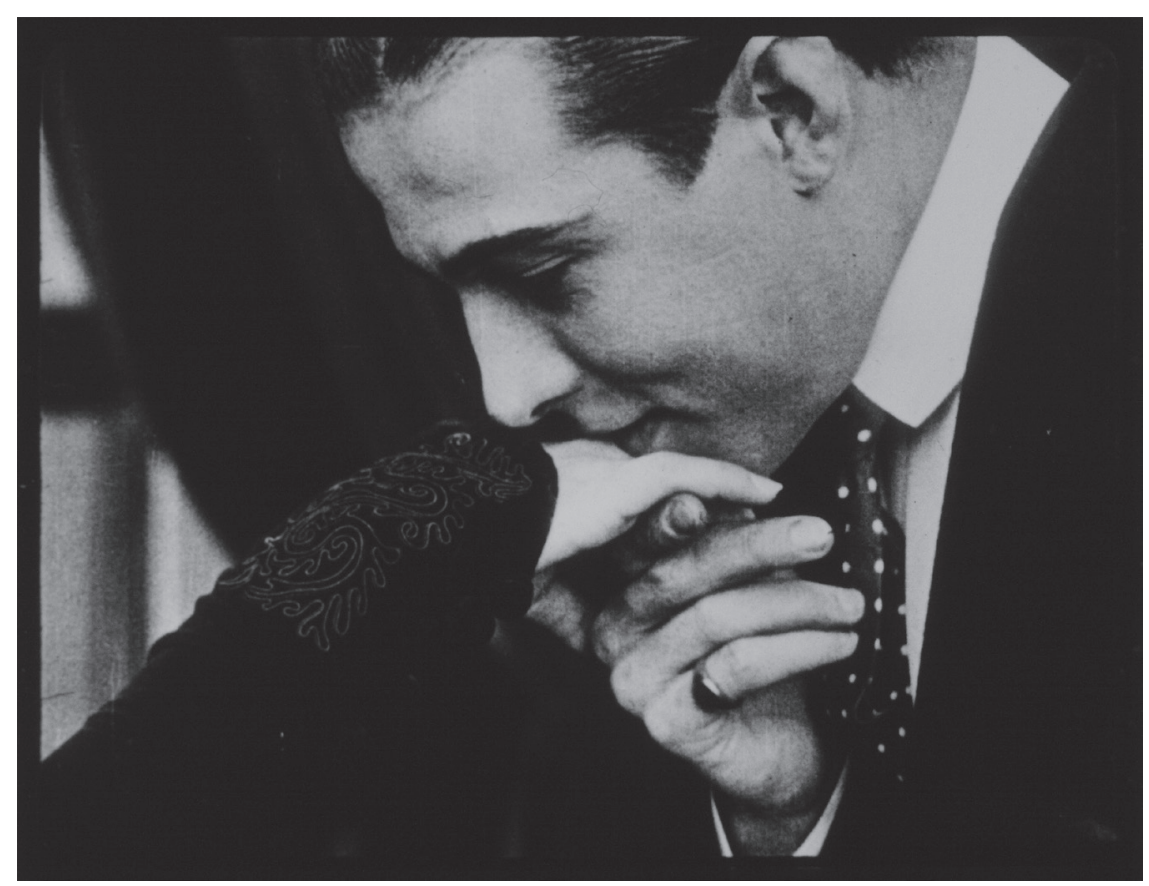

FIGURE 9. Valentino's appealing gallantry in The Married Virgin (1918), frame enlargement. Courtesy of CINEMATEK, Brussels.

intertitle). Mary succumbs to the plan only after learning from Ethel that unless she weds the "fortune hunter," as Ethel describes him, her father will go to prison.

While the moral compass of the film's overall narrative appears unambiguous, the depiction of the charming Roberto does not invite complete condemnation. Shortly after the wedding, Roberto reveals a surprisingly sympathetic side. After being reassured about the post-wedding check in exchange for the infamous revolver, he appears respectful of Mary's body and emotions. He suggests the marital arrangement of two sleeping quarters: "We are a house divided. Your half is there-mine here." But his charming and seductive temperament leaves the door open to change: the arrangement, he suggests, "shall continue so-until you come to me of your own free will." These are not the suggestions of a wholly disagreeable character, and they are what allows Mary to remain the "married virgin" of the film's title, even if precariously so. Insisting on his (partially) evil and scheming nature, the film sympathetically displays Roberto's visible pain for this chaste arrangement that he has forced upon himself. Only after witnessing Ethel's car accident and drinking himself into a stupor does he abandon all respectful manners, invade Mary's space, and attempt to rape her. The maid's successful display of a cross as a last resort to protect a horrified Mary prevents the inebriated Roberto 
from pursuing the vile action. The final scene, in which he confesses his love for Ethel, his indifference to Mary, and desire to return to South America sounds more like a convenient ideological closure. It excludes future interference in the happy life reserved for Mary, whose unconsummated marriage is quickly annulled, and her less-than-exciting Doug.

The few moments in which Roberto manages to charm Mary may have been a novelty for a motion picture but did not constitute a novelty tout court. American women's fascination for the elegant and noble foreigner was a common cautionary tale, popular in newspaper accounts about tango teas. Such narratives had to convey the attractiveness of the refined and exotic "tango pirate," while also showing foreigners' moral threat to the Anglo-Saxon race. Still, the role of the "slick foreigner, treacherous gangster, foul blackmailer, and disreputable gigolo" may have been hard to accept for an actor who had been branded with similarly infamous charges in real life. ${ }^{39}$ His hunger for the admiration and praise he had usually received on the dance floor, however, might have matched the recognition-his own and that of those casting him - that these film roles embodied a widespread fantasy of fear and desire that the film's fictional diegesis made safe for actors and spectators alike. It was the fantasy of surrendering to the expert seduction of a Latin foreigner, without sexual consummation, but with plentiful display of erotic desire. ${ }^{40}$ The Paramount promotion that appeared that year courted exactly such a salacious imaginary. It described Valentino as "the handsomest lounge lizard that ever infested a tea dansant," while referring to Mary as "the girl who deliberately marries a man who she feared." ${ }^{41}$

During this period, not every film that availed itself of Valentino's presence cast him in this kind of role, and their publicity rarely exploited or enhanced his dangerous appeal. It probably did not help that, after dropping his last name, Guglielmi, as too hard to pronounce and too easy to associate with the de Saulles scandal, he kept changing his moniker. Initially, Valentino used variations that evoked or replicated the name of the saint associated with courtly love or Cesare Borgia's noble title (Duca Valentino). This resulted in either a noble-sounding double name (De Valentino, di Valentino, De Valentina, di Valentini) or a single one (Valentine, Volantino, Valentino). ${ }^{42}$ Several unremarkable films typecast his Latin mannerisms into morally devious roles. Either alien or just exotic looking, he appeared prone to exploit either his attractiveness or brutality, or both. In 1919, he was cast as a thug from the Bowery in Virtuous Sinners, an accomplice in a gang of thieves in The Homebreaker, a fatuous and cheating boyfriend in The Big Little Person, and a tough Montmartre apache dancer in A Rogue's Romance. He was also a sinister figure bound to ruin the life of the female protagonist in Nobody Home / Out of Luck (August 1919), a scheming Frenchman in An Adventuress (1920), and a notorious criminal in The Wonderful Chance (1920).

While these films translated his exotic Mediterranean appearance into morally disagreeable roles, they did not systematically cast him as a foreigner. Consider The 
Delicious Little Devil (Universal, 1919), in which he played the role of a wealthy and hypocritical young man named Jimmy Calhoun, who is afraid to propose marriage to a young dancer, played by Valentino's friend and early advocate, Mae Murray. Sporting heavy makeup but no sign of racial otherness, his dancing skills are rarely exploited even though several scenes take place in a cabaret. His most common emotional state is one of shyness and demure restraint, interrupted only once by a sudden outburst of anger: the charming and passionate temperament that would characterize his early popular films is missing (figure 10). These roles indicate that studios and filmmakers did not yet know how best to cast him for productions designed for mass audiences. What was clear, however, was that Valentino's charming appearance could not be confused with the kind of Beban-like characters that would have associated him with Italian immigrants. Even in the films in which he appeared more a victim than a creator of circumstances, his most constant characteristics were his personal elegance, proud bearing, and high social status. ${ }^{43}$

A turning point apparently occurred with Eyes of Youth (Garson Productions, October 1919). Adapted from the popular eponymous 1917 play by Max Marcin and Charles Guernon, the film explores the choice between true love and financial convenience faced by a young American opera singer, played by popular screen personality Clara Kimball Young. Valentino is cast not as an Italian but as "Clarence Morgan, a cabaret parasite," as one intertitle introduces him. The protagonist, Gina Ashling, is married to a rich man who, after growing tired of her, has hired the young seducer Clarence to discredit her reputation so that he can get a divorce and remarry. Clarence invites Gina to his place and assaults her just before her husband and his lawyers burst into the apartment and pretend to witness a conjugal betrayal (figure 11). A married woman in the company of a young and dashing Latin-looking man played by Valentino was a familiar scene. At the trial, she describes Clarence as "a man without honor-and without conscience." The outcome of the legal proceedings matters greatly to Gina, but what is also at stake, as the film emphasizes, is her public reputation. An intriguingly animated intertitle first juxtaposes the court of law with that of public opinion: "Guiltless! Condemned by the merciless judge, Public Opinion- 'To hell for life and no parole!'” The same title card then shows a folded newspaper intruding into the printed text, revealing an article bearing the unforgiving headline "Financier Goring Charges Wife with Infidelity" placed above a close-up photo of her. The film was a success. Variety greeted it as "a knockout" and even avoided summarizing it, for "the story of the play is too well known." 44 In its twisted plot, in fact, the film's insistence on newspaper coverage of an adultery trial featuring a once-respectable couple and a slick and charming young gigolo likely evoked the de Saulles scandal and other similar ones. But not many people could have known that the film's Rudolfo Valentino was Rodolpho Guglielmi. Taking part in a fictionalization of events reminiscent of the heavily reported New York affair could have been a career-killer move. Instead, it turned out to be the opportunity of a lifetime. 


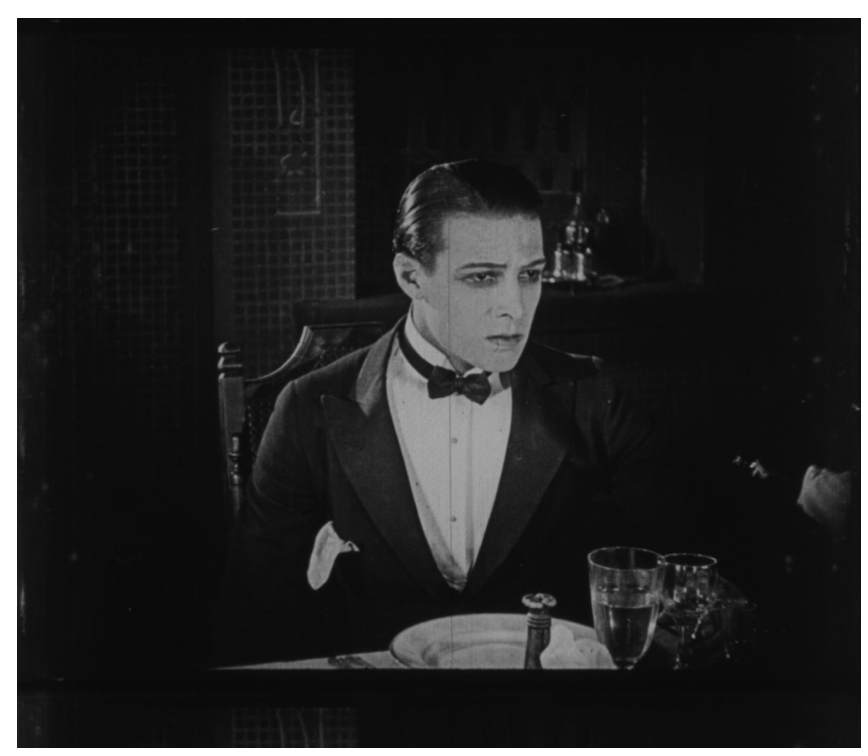

FIGURE 10. Valentino as the sad and restrained Jimmy Calhoun in The Delicious Little Devil (1919), frame enlargement. Courtesy of EYE Filmmuseum, Amsterdam.

According to several accounts, among the attentive spectators of Eyes of Youth was Metro's top screenwriter and executive, June Mathis, who would later play a key role in casting Valentino in The Four Horsemen. It is fair to assume, however, that the links between Mathis and Valentino were less serendipitous than what this single film viewing might suggest. Mathis was commercially as well as artistically ambitious and had many connections in the world of the stage and motion pictures. Some of those connections knew the Italian actor. Certainly, in the wake of his interpretation in Eyes of Youth, Mathis might have remembered his talent as a dancer, including his reputation as tango pirate, his physical traits, and perhaps his temperament on and off screen. It is also likely that Mathis, based in New York at the time, had become familiar with the scandal of the de Saulles family. Could she have connected the Rodolpho Guglielmi of the de Saulles scandal with the Rudolfo Valentino of Eyes of Youth?

The degrees of separation between the two were few and revolved around the Russian actress Alla Nazimova and Metro Pictures. In the late 1910s, Mathis had scripted a few pictures at Metro starring Nazimova, including Eye for Eye (1918) and Out of the Fog (1919), and possibly knew of her friends, famous parties, and occasional lovers. ${ }^{45}$ One of them was actress Jean Acker. In November 1919, a month after the release of Eyes of Youth, the fairly established Acker suddenly wed the less-known Valentino in what quickly turned out to be an ill-fated marriage. 


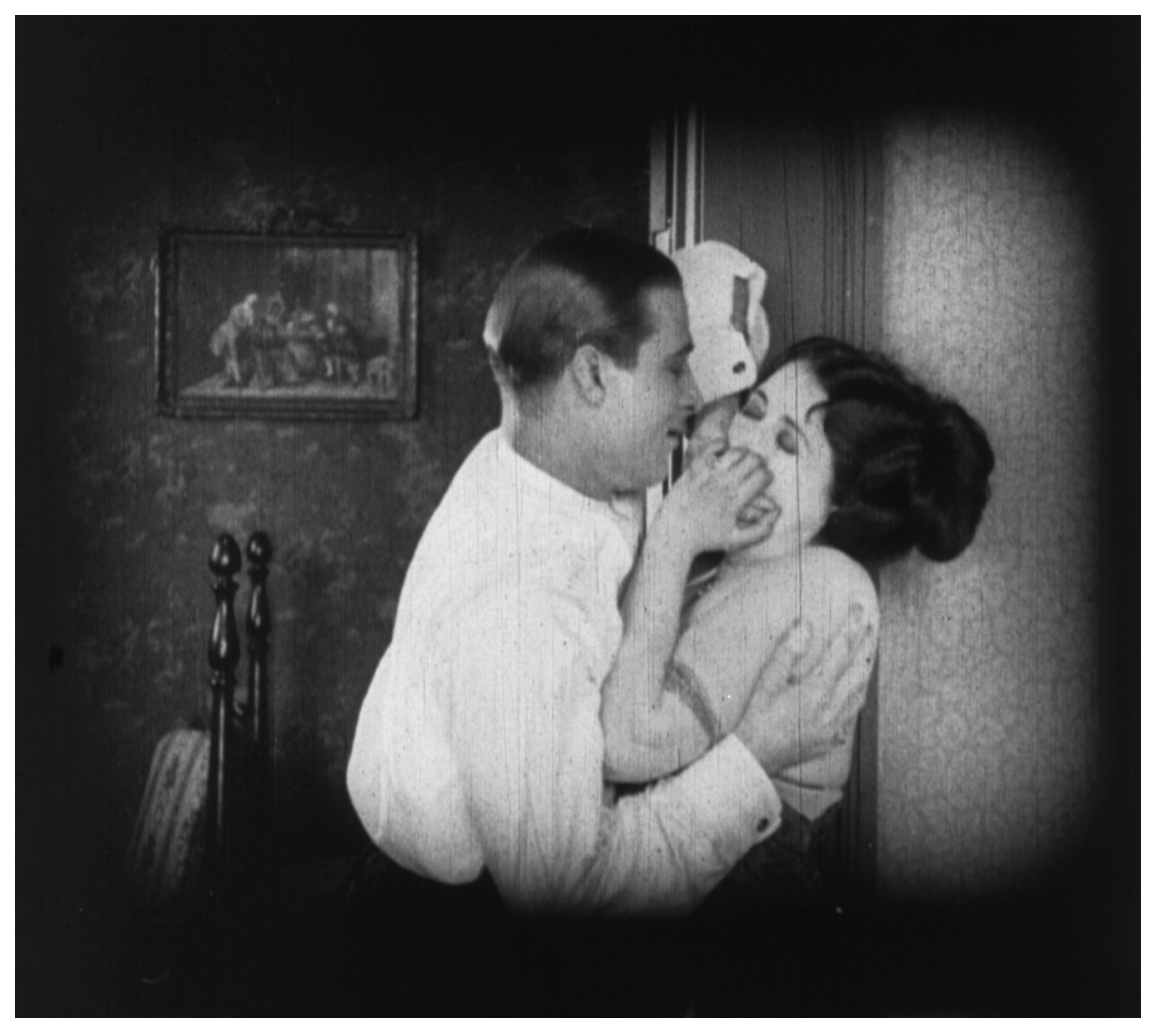

FIGURE 11. Valentino stifling the cries of an innocent wife (Clara Kimball Young) to stage their consensual rendezvous in Eyes of Youth (1919), frame enlargement. Reproduced from the collections of the Library of Congress, Moving Image Section.

The wedding received a singular, rarely discussed imprimatur from Mathis's own company, Metro Pictures. The couple's best man was Metro's general manager, Maxwell Karger, and the wedding celebration took place at the home of the company's treasurer and in the presence of the company's president, Richard Rowland. ${ }^{46}$ It is unlikely Mathis was absent; it is impossible that she was not aware of the ceremony and of who was Acker's groom. More than just an actor who caught her eye in a screening of Eyes of Youth, Valentino was certainly an acquaintance connected to Mathis's close circle of friends and coworkers and an individual whose liaisons with married women had made headlines in the press and had been used twice on film. Mathis might have recognized something original in his film performances, but her casting of Valentino in The Four Horsemen also depended on her personal and professional identity-gender, talent, and ambition - and on the film's promising international appeal and resulting promotional campaign. 


\section{A WOMAN'S (COMMERCIAL) VIEWPOINT}

Mathis was much more than a scenario writer. She was a writing supervisor, an editorial director, and a film producer-a combination that "allowed her to control the writing ideas she guided onto the screen" and to be voted in 1926 the third most influential woman in the history of motion pictures. ${ }^{47}$ She wrote countless scripts, first as one of Metro Pictures' scenarists then as its editor-in-chief. Between 1921 and 1922 Mathis completed five scenarios for Valentino, beginning with The Four Horsemen, Camille, The Conquering Power and, in 1922, Blood and Sand and The Young Rajah. Her later writing credits included other major accomplishments such as Eric von Stroheim's Greed (1924) and Ben Hur (1925). No matter how much recognition her work received, her name remained closely associated to that of the Italian actor whom she had allegedly discovered and launched to superstar fame. When she suddenly died in 1927, less than a year after Valentino's passing, her New York Times front-page obituary read: "June Mathis, world-famous motion picture scenarist, who adapted 'The Four Horsemen of the Apocalypse' for the movies and discovered Rudolph Valentino, died last night." ${ }^{38}$

In recent years, the critical discourse about Mathis has tended to pair her superb talent with an artistic and (proto)feminist poetics. "Mathis was committed to 'artistic' filmmaking as opposed to the formulaic films turned out by many women writers in Hollywood," Donna Casella has argued, and she explored "sexual, racial and national themes in her films, with particular attention to woman as a social force." 49 Her personal approach, critics agreed, was already visible in the subversive female roles she had designed during the war as well as in the scouting of her unconventional leading men against the background of the patriarchal and nativist ethos of both Hollywood and America. ${ }^{50}$ Regarding her scripts for Valentino and in dialogue with Gaylyn Studlar and Miriam Hansen's insights into his ambivalent masculinity, Thomas H. Slater has also argued that Mathis's scripts construct a fragile, fatherless man who has to rely on the figure of a strong, spiritually sound and sexually mature woman to test his masculinity and either find himself or fail..$^{51}$ In the wake of "the world war's desecration of masculinity," Mathis's Valentinos "were not athletic action heroes unencumbered by family and social concerns as were Fairbanks's characters" but "'wounded" figures who required an alternative to violence and adventure as a basis for identity." In Slater's view, Valentino "did not become as wildly popular among men and boys" because he was not attuned to the "boy culture" that Studlar has recognized in Fairbanks's celebration of rugged masculinity.52 Instead, he argues, Mathis's scripts designed Valentino as a character who views the future "with dread (Blood and Sand), hopefulness (The Conquering Power), or uncertainty (The Four Horsemen, Camille)," and for whom death is the ultimate horizon of personal actualization or failure. The danger of war (or of bullfighting) served as the grounding moment of patriarchal failure and personal crisis. The risk of personal bereavement did not just imply the deconstruction of traditional masculinity, but also anticipated 
its novel reconstruction (or "becoming," in Slater's analysis) in ways that were more agreeable to women's imagination..$^{53}$

Slater's critical perspective is centered on an equation of personal expression with a feminist one, and an American one at that. In his analysis, Mathis's scripts are a woman's work in the sense that they express a feminist take on narratives and characters - as if other dimensions played little or no role in her work. Slater's approach appears to downplay two significant professional dynamics: one pertaining to authorship and one to promotion. The first involves the delicate balance in Mathis's screenwriting poetics between the aforementioned ethics of gendered expression and her well-recognized domestic and international commercial aspirations. The second dynamic, which I will explain in the next section, involves the role of publicity in linking Mathis's name to Valentino and in constructing a commercial exploratory space for his novel masculinity in ways not necessarily anticipated by her scripts.

Regarding the first issue, early 1920 s profiles, as well as her own pronouncements, were at pains to reconcile the apparent contradiction between her gender identity and her professional shrewdness. For instance, in The First One Hundred Noted Men and Women of the Screen (1920), author Carolyn Lowrey sought to reassure her readers that the author of the script of To Hell with the Kaiser, which Variety had praised as a "wonderfully effective propaganda film," had not lost her femininity, despite her professional drive and success. ${ }^{54}$ In an effort that we may find trivial, Lowrey noted the presence of flowers in Mathis's book-lined office and described the décor as "original [and] in many respects delightfully feminine." 55 Here the reference to her femininity worked to correct and thus downplay her exceptional talent and dogged determination. Lowrey, however, added a critical qualification to her success that had great resonance at the time: she praised the professional quality of Mathis's work by commending her ability to register a prevalent temperament and draw popular characters, rather than regarding her work as a form of mere artistic expression. To Lowrey, if scenarios constitute "the base from which the cinema makes its public appeal," Mathis's ones were what stood "behind the popularity of many stars." ${ }^{6}$

Mathis herself had stressed her sensibility for public opinion in a New York Times article from the spring of 1923. "Quite often I have picked out something that appealed to me as being wonderfully dramatic, but which has not made the same impression upon other readers," she wrote about her process of adapting famous novels. To modulate and expand her positive first impressions into developed screen treatments, Mathis had a careful two-step method that first involved "noting down each point and the number of persons in favor of it" before deciding on the dramatic points of the scenario on the basis of at least seven favorable opinions out of ten. ${ }^{57}$ Two years later, in a contribution to the Film Daily, she summarized this approach by linking a "female perspective" in moving pictures to questions not just of gendered expression but also of commercial viability and success-which may not have been 
any less subversive. After noting that scenarios had to appeal to millions of spectators and that women played a huge role in reaching that goal ("of those millions the hand that rocks the cradle is the ruling spirit"), she celebrated the significance of having female scenario writers, art directors and set dressers, for "they understand the decoration of the home, the setting of tables, the arrangement of flowers." ${ }^{8}$ The most difficult thing for men to acknowledge is that "there is such a thing as a woman's viewpoint that is possibly commercial" and that a "magic something" impossible to ignore had "made American films supreme in the world's market.59 As her promotion of Valentino would show, women spectators could be won much more easily by an exotic leading man than through floral arrangements.

\section{THE TANGO DANCER BECOMES A STAR}

The available evidence on the production of Valentino's breakout film raises important questions about June Mathis's actual contribution and specifically about the difference between the protagonist of her script and the lead character that the studio ended up promoting after the film's release.

In early 1919, Metro had purchased the screen rights to the best-selling novel Four Horsemen of the Apocalypse. First published in 1916, the book by the Spanish writer Vicente Blasco Ibáñez (1867-1928) had reached about 170 editions worldwide, including as a Photoplay movie tie-in edition (1918). An established version of the facts suggests that Mathis chose to adapt it against the opinion of the film industry's top leaders. As the story goes, Hollywood producers mistakenly believed that the novel had a complicated plot and would require an expensive production. Moreover, by the end of the 1910 s war subjects were believed to be no longer appealing to an American public eager for lighter fare. ${ }^{60}$ Yet, the truth appears to be somewhat different: Mathis played a remarkable role, but the selection of the novel may not have been her idea.

In March 1919, the first coverage of Metro's purchase of the rights does mention her name in conjunction with the planned adaptation but also indicates that Metro president Rowland had secured the filming rights to the novel after personally meeting Ibáñez during the author's brief stay in New York City. ${ }^{61}$ Only then, Rowland communicated his actions to Mathis and "hurriedly summoned" her to New York to meet the novelist and "undertake at once the screen adaptation and scenarioization of the novel." ${ }^{2}$ As newly promoted head of Metro's Scenario Department, she took full charge of the project. Together with the studio's key figures, Loew, Rowland, and Maxwell Karger, Mathis met again with Ibáñez during his late February 1920 visit to Hollywood to discuss the project. Their meetings were made part of the film's promotion (figure 12). ${ }^{63}$

Coverage of the months leading up to the film's shooting sheds some light on its commercial raison dêtre. Right before the cameras rolled, a late December 1919 issue of Moving Picture World (MPW) summarized a speech given by Rowland in 


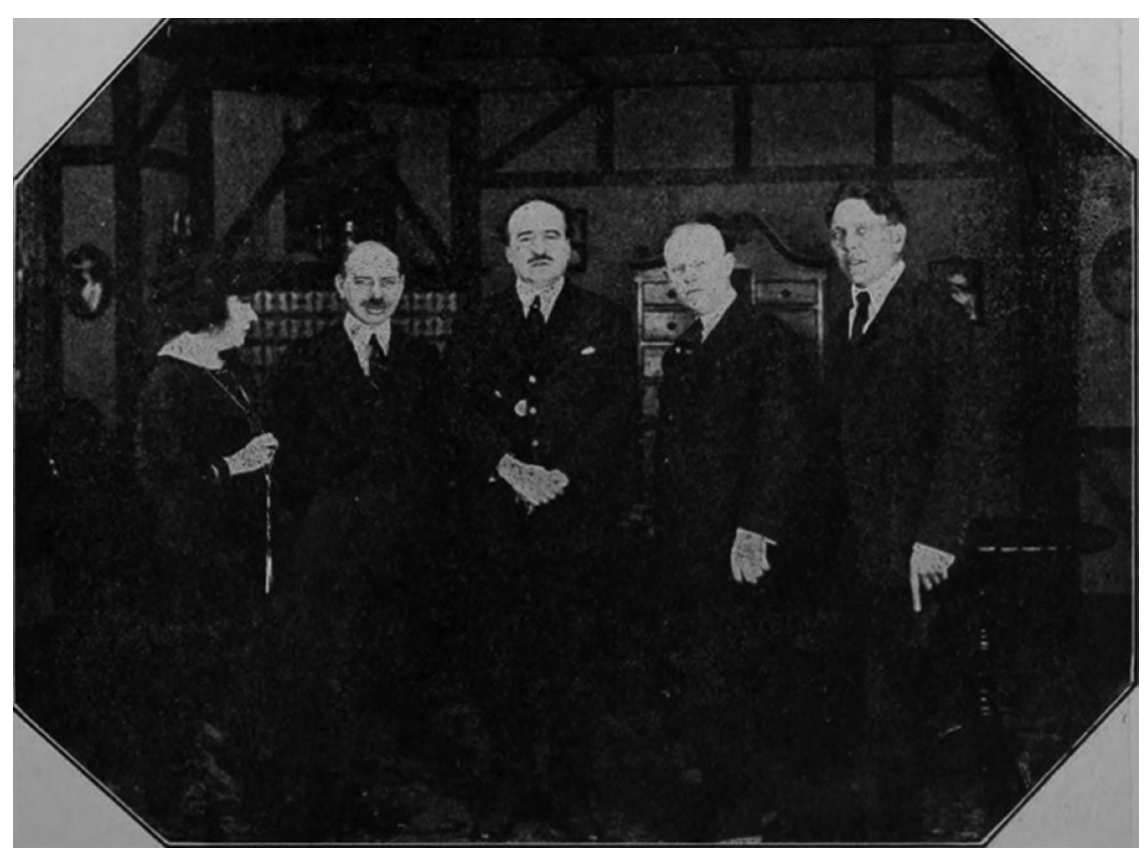

FIGURE 12. Key figures at Metro Studios. From left: June Mathis, Marcus Loew, Vicente Blasco Ibáñez, Metro president Richard A. Rowland, and Metro treasurer Maxwell Karger. Moving Picture World, March 6, 1920, 1657.

New York in which he described what he considered two incontrovertible facts. The first was "that American producers must make concessions to foreign distributors because of the present disparity in money exchange." The second one was "the entry of so-called big business into the motion picture industry," which he viewed as "an inevitable step which need cause no alarm especially to the independent exhibitor." ${ }^{34}$ Rowland was quite familiar with the European market after a twomonth trip to Europe, where he had interviewed prominent film manufacturers and distributors. In the wake of the growth of the film business, which had finally turned into a "legitimate field for investment" and was becoming ever "stronger in the popular affections," he reflected on the surge of "high-grade pictures." It was in this very context of business corporatization and secured international appeal that Rowland mentioned in the MPW article Metro's "latest coup": the acquisition of "the sensational novel by Vicente Blasco Ibanez." 65

If Rowland was quick to stress the commercial prospects associated with the popular novel's film adaptation, Mathis may have sensed a unique opportunity to combine high professional aspirations with her own poetics. "The bigger the subject, the bigger the inspiration," she declared in an interview orchestrated to appear in the same issue. ${ }^{66}$ In order to grasp how Mathis set out to adapt the almost 
five-hundred-page book into a film script, cast protagonists, and aim for the widest possible success, we must turn briefly to Ibáñez who, already in his early fifties, had authored very different kinds of novels and was an established figure in world literary circles.

The critical canon about his output tends to differentiate between the naturalism of the early works and the controversial psychological sensationalism of his subsequent output, of which Blood and Sand (1908) is the most famous work. Established Spanish critics viewed his later attention to the slum dwellers and lower classes in general as an attack against the church, the monarchy, and the army. ${ }^{67}$ Los cuatro jinetes del Apocalipsis belonged to a third phase, comprising war novels that feature a cosmopolitan sensibility that found great success in Hollywood. ${ }^{6}$ Los cuatro jinetes tells the story of an aging authoritarian Argentinian landowner whose grandsons, fathered by his French and German sons-in-law, return to Europe at the outbreak of the First World War and find themselves fighting on opposite sides. For Ibáñez, who was living in Southern France at the time and had befriended French political leaders, the novel was an opportunity to make a broad geopolitical statement. The nation's president, Raymond Poincaré, had invited him to visit the site of the Battle of the Marne with the hope that Ibánez would use it in one of his novels and thus support the French cause. In Los cuatro jinetes, the novelist gave a remarkably realistic account of the battle, together with an exposé of one of the most controversial aspects of German Kultur: its militarism. The resulting novel, as critics later noted, was "an impressive feat of propaganda." ${ }^{9}$

History provided help. The book's translator, Charlotte Brewster Jordan, bought the book's U.S. publishing rights for only \$300 shortly after its 1916 publication. Yet, few could imagine the impact of America's April 1917 declaration of war on the book's release nearly a year later. In the first ninety days after its publication, the volume sold about ninety thousand copies and, within a few more months, it reached twenty editions for a total of more than two hundred thousand copies. What is rarely acknowledged is that Ibáñez was a master self-promoter who did not hesitate to merge conventional literary promotion with mass commercial advertisement. "There are silks, cigarettes, soaps, toys, whose brands include the same image of The Four Horsemen that is on the cover of my novel," he told the Spanish press in 1919. ${ }^{70}$ A year later he traveled to North America for a series of conferences in New York, Chicago, and Toronto, among other cities. ${ }^{71}$ In late 1921, in the wake of the novel's tremendous success, Ibáñez proudly described himself as a "universal film novelist" (novelista universal cinematográfico). ${ }^{72}$ It is reasonable to assume that Mathis (and Rowland before her) found Ibáñez's wartime fame and notorious ability to connect to a mass readership quite appealing. Mathis likely met with him several times, and, while she must have had great respect for his literary inventiveness and popularity, she also had clear ideas about his novel's cinematic adaptation. ${ }^{73}$ 
As an efficient manager, Mathis was to take control of cast and crew. Her choice for director fell on Rex Ingram, who had a notoriously difficult temperament but with whom she had collaborated quite well a year before on the now-lost Hearts Are Trumps. ${ }^{74}$ For her leading man, she needed an exotic actor flexible enough to play a privileged young Argentine, a Montmartre artist and poseur, a gifted tango dancer, and a fantastic lover who ends up sacrificing his life to win the approval of the woman he loves. Some commentators at the time and later critics have described Valentino as "raw material" who could be transformed from a "thickset young Italian peasant into an elegant Argentinian nobleman." One may argue instead that his scandalous previous roles in life and on film as slick tango dancer and seducer of married women, in addition to being part of Mathis's circle, made him more a sound choice than a long shot. ${ }^{75}$

While the extent to which Mathis expected that Valentino would become a runaway star after the film's release is unclear, her changes to the ways Julio enters and exits the story reveal her ideas about his role. In the novel, Julio is neither the protagonist nor the main hero. Those roles are reserved for Julio's father, the old Desnoyers, and the Russian mystic, Tchernoff, who promotes Christianity as true revolution and whose centrality explains the novel's title. In Mathis's surviving script, title sheet, and the finished film, which she closely supervised, however, Julio Desnoyers is a leading figure, deserving a grand introduction and undergoing a sympathy-inducing transformation, indeed a conversion, from spoiled womanizer to romantic and patriotic martyr. ${ }^{76}$ In the film, Mathis introduces Julio as a leading man with the famous tango scene set in Buenos Aires (figure 13) and thus early in the narrative and not, as the novel does, later in Paris after the beginning of the war (figure 14). Secondly, she purifies Julio's reasons for his transformation by linking them to a noble search for romantic approval. In the novel, Julio's motivations for his apparent change are merely utilitarian, linked to a selfish desire to maintain admiration from his beloved and the world around him. Finally, Mathis's construction of the character of Julio did not exactly coincide with how the studio set up the film's promotion, which followed the novel's plot, not Mathis's own rewriting.

Thus, the film's most memorable scene, set in a working-class Buenos Aires café with Valentino leading a tango dance before a variety of admiring characters, is, strictly speaking, absent from the novel. A comparable scene is set in Paris and thus unfolds much later in the story. Moving the tango scene to the Argentinian capital was apparently Mathis's idea and helped to establish Julio as leading man and set up his development and transformation from early on. In Buenos Aires, Julio can appear in full gaucho regalia and can display an exotic authenticity that the film spectators can project onto the Parisian tango when, wearing a splendid tuxedo, he can impress his married companion with the dance learned in his boyhood. But by then he is already undergoing a personal transformation. The initial publicity did not distinguish between the two tango scenes; instead it confused them. It advertised illustrations from the Buenos Aires film sequence, with Julio 

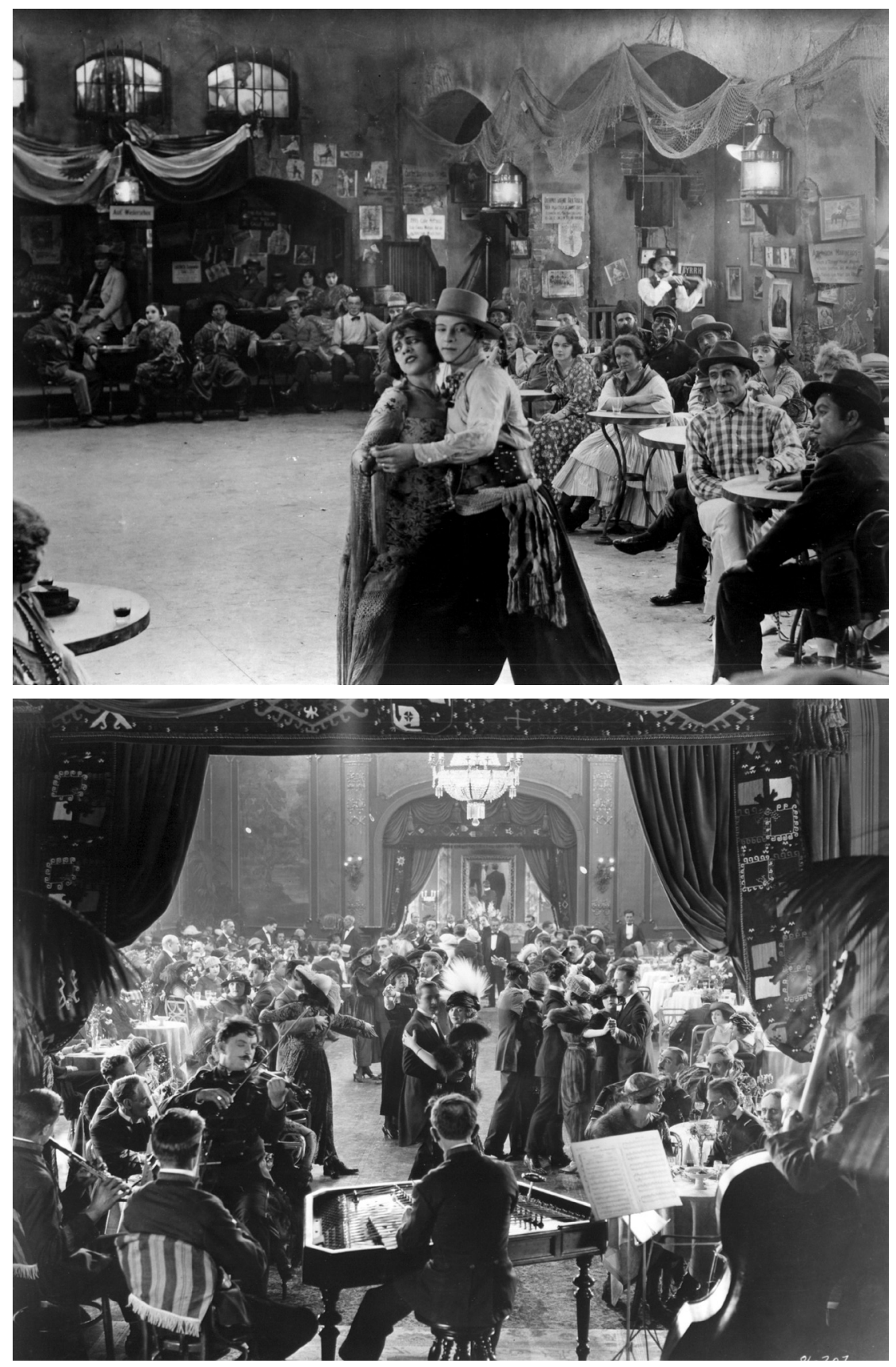

FIGURES 13 and 14. Pure exoticism versus charming elegance in The Four Horsemen of the Apocalypse (1921): the tango scenes in Buenos Aires and in Paris. Courtesy of Museum of Modern Art Film Stills Archive. 
in Argentinian costumes, by attributing it to a Paris setting and thus following readers' expectations.

Still, the famous scene was not entirely Mathis's invention. She had reworked information from Ibáñez's novel that conveyed, about seventy pages in, Julio's dissipated lifestyle, made of "imprudent borrowings" that the patriarchal Madariaga had encouraged. ${ }^{77}$ Ibáñez had also stressed Julio's leadership by depicting him as "ringleader of a band of toughs in the Capital" who liked to recount his "nightly escapades" of "gay, wild life" to his eager grandfather. ${ }^{78}$

In both texts, Julio's life of vice, debauchery, and vulgar romance-and their representation-does not last long, but the difference is that in the film, he displays signs of authentic change before moving to Europe. In Mathis's film treatment, for instance, when Madariaga gives unmistakable signs of failing health, Julio's self-confidence diminishes dramatically. Further, the film scene showing Julio's desperate reaction to the reading of Madariaga's will, in which the old man did not single him out as a special heir, constitutes an original addition; it is absent from the novel. In Ibañez's work, Julio apparently undergoes some change between Argentina and Paris, but it is more a superficial makeover than a conversion. In Paris, Ibáñez's Julio continues to attract and enjoy public admiration as a tango dancer, displaying a thirst for attention and praise that grows subdued and almost disappears in Mathis's character. Since the novel casts Julio as a remarkable character but not as protagonist, its author can delay the description of the tango's tantalizing appeal until well into the story. When Ibáñez writes that the Argentinian dance was "in full swing in Paris" and that it had become "a new pleasure for the delight of humanity," he is detailing the exotic appeal with which Mathis charged her new leading man from the film's opening and which in her script set the stage for his conversion. ${ }^{79}$ Ibáñez's description of the tango unfolds in pure physical, caveman-like terms, and centers on the Euro-American's co-optation of subversive and racially different scripts of romance.

The tango had taken possession of the world. It was the heroic hymn of a humanity that was suddenly concentrating its aspirations on the harmonious rhythm of the thigh joints, measuring its intelligence by the agility of its feet. An incoherent and monotonous music of African inspiration was satisfying the artistic ideals of a society that required nothing better. The world was dancing . . dancing . . dancing. ${ }^{80}$

The tango fever crowned Ibáñez's Julio as the ruler over the Parisian tango teas and champion in the art of romance. While "appraising his slender elegance, medium stature, and muscular springs," ladies hoped to be seen being held "in the arms of the master." ${ }^{81}$ In the film, by contrast, the Parisian Julio is bound to differ from his earlier, frivolous days. While he seems to remain dependent on his mother for financial support, he regains some measure of control over his destiny and his identity as a painter-a picture-maker, that is. Further, his falling in love with a married woman, Marguerite Laurier (Alice Terry), challenges his emotional immaturity: she is wiser and more sensitive than he is, particularly regarding the tragedy of war. 
While she is initially delighted that the mandatory conscription of all able-bodied French men has spared her Argentine lover, she is soon overwhelmed by feelings of guilt and remorse for her adulterous affair. Deciding to nurse her husband, who has just returned blind and disabled from the front, Marguerite separates herself from Julio. In a combination of admiration for her sacrifice and desire to please his father, who many years earlier had escaped conscription by moving to Argentina, Mathis's Julio undergoes a spiritual transformation (figure 15). He volunteers for the French army and becomes a selfless man driven by romantic abnegation and ultimately patriotic self-sacrifice.

In the novel, his motivation is less honorable. Julio is drawn to Marguerite because her combination of "confident advances" and "capricious outbursts of modesty" represents "a new type for him." ${ }^{82}$ After the war starts, Marguerite's complex new emotions divide them. Revealingly, her inconsolable reaction to her brother's death in battle "did not please his amorous egoism." ${ }^{8_{3}}$ Julio notices that the times are changing, as admiration for selfish individuality is giving away to "a new lovea love for the man who is suffering, desire for abnegation, for sacrifice." Rather than being inspired by the new idealism, he cynically registers the change as a new form of popular taste and not as a spiritual transformation. ${ }^{84}$ When his female fans ask him why he is not wearing a uniform or going to the front, Julio realizes that he is "no longer fashionable" and that the age of the "tango is dead." Similarly, when toward the end of the novel Julio reaches Bordeaux, where Marguerite is caring for her wounded husband, he realizes that she considers her older spouse to be a man far superior to her younger lover. This realization provokes his decision to enlist immediately, out of a "hasty heroism" though not out of a spiritual or patriotic élan. Even the ensuing internal dialogue, in which he imagines himself a soldier, reveals a fatuous and narcissistic nature still driven to attain personal glory: "Soon she would hear him well spoken of," for he would either die right away or "astound the world by his bravery." ${ }^{86}$ Once enlisted, however, Ibáñez's Julio practically disappears. He dies in battle, but no details are given regarding the circumstances. When his father visits his "rustic grave" in a vast burial site, he considers building a mausoleum for his son before realizing the uselessness of it all. Likewise, Julio's sister cannot even keep him in her mind for more than few moments. And there the book ends. ${ }^{87}$

The Spanish writer bestowed upon the young man the ability to act differently, to take new actions, but not to feel differently and grow intimately. By contrast, the film's narrative division between Argentina and France is startling not just because the tango's wild otherness is confined to Buenos Aires and downplayed in Paris, but also because it showcases Julio's transformation from self-centered playboy to spiritual lover, sensitive to the call of duty and to Tchernoff's teaching. ${ }^{88}$ Mathis's presumed interest in constructing a more sympathetic male character, one whose virile leadership eventually gives way to selfless sacrifice, bestowed upon the role of Julio more narrative and emotional weight and found fertile ground in the film's 


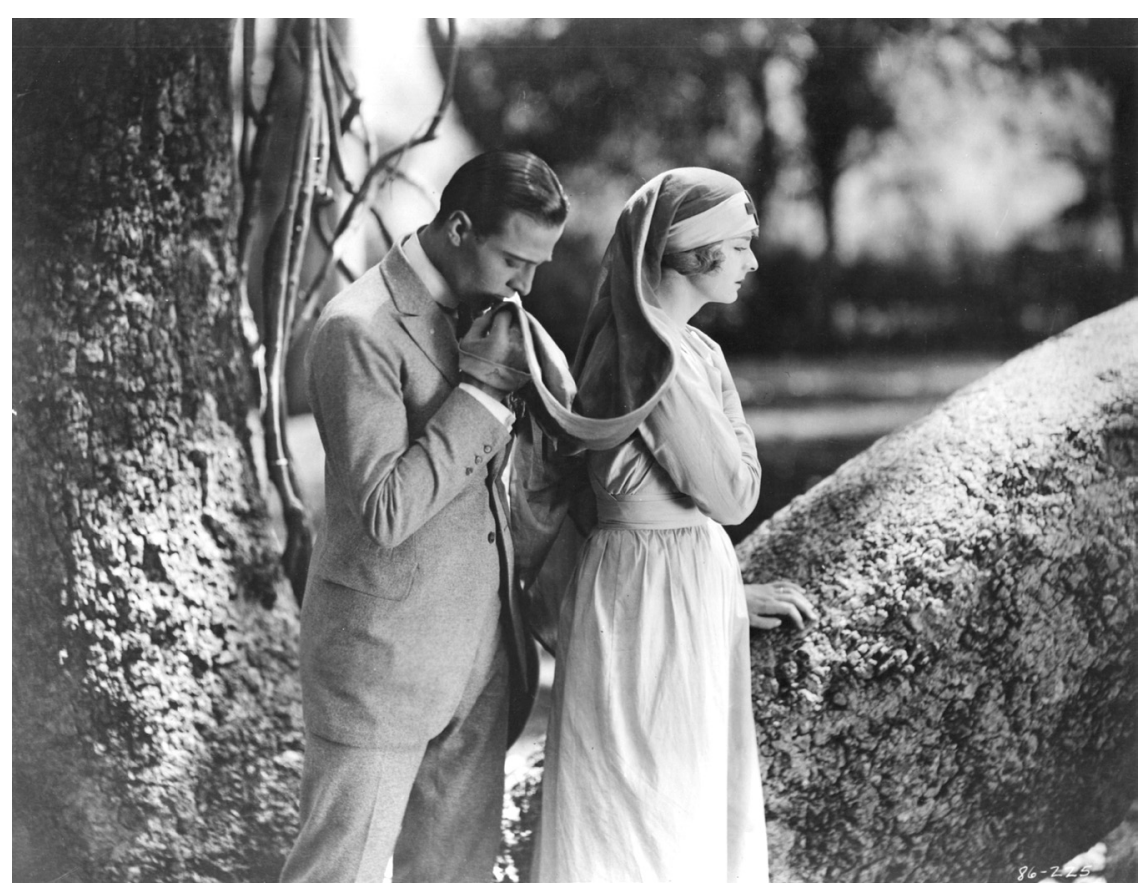

FIGURE 15. Valentino's spiritual conversion in The Four Horsemen of the Apocalypse (1921), leading to voluntary military service and, ultimately, personal sacrifice. Courtesy of Museum of Modern Art Film Stills Archive.

attendant promotion. Still, what The Four Horsemen's publicity achieved was to launch Valentino as a Latin-lover star who was rather different from the sensitive Julio with which Mathis had ended her script and much closer to the tango dancer of the film's beginning. The primacy effect of the tango scene prevailed over the film's narrative trajectory and resolution.

\section{LAUNCHING THE APOCALYPSE}

In line with the epic status of the production, the publicity for The Four Horsemen was most effective. During the film's production, Moving Picture World publicized the historical accuracy of the war scenes, for which "army officers, war correspondents and other experts have been consulted," as well as their scalean "entire French village had been built to be destroyed""s The company also created pseudo-events, including a "poster drawing contest," 90 and filled the pages of trade journals with images of Valentino in a tango outfit and of gauchos riding through Argentina's open spaces. ${ }^{91}$ The film's New York premiere, held on March 6, 1921, was a public celebration of cinema's geopolitical relevance. The film's link to 
World War I brought together a heterogeneous assemblage of film celebrities, politicians, and powerful individuals. In attendance were the Spanish and Argentine ambassadors from Washington in addition to Nicholas Murray Butler, president of Columbia University, Winston Churchill, Adolph Zukor, Anita Loos, John Emerson, Lee Shubert, and David Belasco, among others. ${ }^{92}$

The initial publicity around the premiere reveals an element that the critical discourse on the film has often overlooked: the massive community of the novel's readers. $M P W$ insisted that the novel "had passed its 161st edition" and "its legion of readers throughout the United States alone [was] estimated at more than 10,000,000 persons."93 A month later, when the film opened at the Astor Theatre, $M P W$ boasted that the number of readers had doubled. ${ }^{94}$ By then, Metro had pulled off what MPW labeled "an outstanding achievement in the publicity for this film." Armed with posters that promoted both the book and the film, it had gained virtual possession of the biggest store windows in New York, from booksellers (McDewitt \& Wilson) to department stores (Lord \& Taylor, Gimbel Brothers, Macy's, Abraham \& Straus). The trade press described it as "one the best window campaigns ever worked anywhere." ${ }^{95}$

After the film's launch, reactions shifted from the celebrated links with the novel and the memory of the war (which the novel had powerfully reignited) to the picture's multiclass appeal. In a Motion Picture News issue that appeared the day before the film's premiere, an anonymous reviewer argued that Ingram's film could not "be called a war picture," since it was "more a study in racial traits with adventure, romance and the effects of war used to give it color." 96 The same reviewer then detailed the features he admired the most: Valentino, "the Argentine," and with him "the natives and their national dance, the primitive white heat of passion [...] all caught and presented in kaleidoscopic proportions." ${ }^{97}$ What years earlier would have been reason for racial and cultural separation became a motif for aesthetic delectation in this most charming of film characters. The studio's publicity material helped a great deal.

A thirty-two-page booklet containing advertising and publicity suggestions for the film, edited by J. E. D. Meader, Metro's New York-based director of advertising and publicity, aided the effort. In addition to information about the costly filming, the booklet included suggestions for several catchphrases ("In which a youthful libertine, useless as a drone and as dangerous, finds that he owes God a death") and two kinds of printed lobby displays-all centered on Valentino's presence. The first suggested display, called "The Argentine," "represents one of the most flashing scenes in the preliminary part of the story: the tango scene where Julio, the spoiled young South American, takes away the dancing partner of another man." The second one, "Paris by Night," depicted "the revels of the hero, Julio, in the days after he went to Paris." 98

For months following its release, The Four Horsemen remained a blockbuster. $M P W$ reported than more than one hundred road companies were exhibiting it-a 
practice that was reserved for special or uniquely successful productions. ${ }^{99}$ At the same time Metro began receiving "unsolicited tributes" from numerous cities and "from all classes of people." 100 Further, the public discourse about the film began to insist less on the merits of the adaptation itself and more on what the industry valued the most: stardom. A few contemporary reviews, from the New York World to the Literary Digest, began to single out Valentino. "The characters used primarily to give color to the picture-South-American natives, Spanish, French, and German specimens," wrote the Literary Digest reviewer, "are all strikingly individualized, and those who have the more extensive roles not only look their parts, but act them intelligibly, especially Rudolph Valentino as the young Julio." ${ }^{101}$ Even Motion Picture Play critic Frederick James Smith, who loudly criticized Mathis's script and Ingram's direction for missing Ibáñez's antiwar message, identified the "early episode of the Argentine cafe" as the film's "highest point." There, he noted, "Julio flashed with life, passion, vibrated across the screen, and the atmosphere radiated with reality." ${ }^{102}$

Mathis may have not necessarily recognized the charming and exotic Valentino that pervaded the emerging publicity discourse, but that image was there to stay. Between The Four Horsemen and his next blockbuster, The Sheik, released in November, a distinct fan discourse began to emerge. In June, for instance, in an article entitled "A Latin Lover," Photoplay boasted the unexpected and fortunate discovery of a star: "Rudolph Valentino played Julio in The Four Horsemen-and immediately the film world knew it had the continental hero, the polished foreigner, the modern Don Juan in its unsuspecting midst." ${ }^{103}$ The trope of exceptional and exotic sensuality soon dominated his highly individualized early reception and found expression in a classic publicity vehicle, the biographical profile-part personal story, part publicity device. Already established for Pickford and Fairbanks and for a wide range of actors who never became big stars, this journalistic genre boosted Valentino's fame and generated a fascination that it would be erroneous to describe as unmediated or spontaneous.

\section{PROFILING}

One of the earliest of a long list of biographical profiles that would not stop even after his death appeared in Motion Picture Magazine. Penned by film critic Gordon Gassaway and entitled the "The Erstwhile Landscape Gardener," the profile sought to legitimize Valentino's status as a star. It portrays him as a talented Italian actor whose life and manners defy the negative stereotypes associated with Italian immigrants and appeal to American and world audiences alike. Accompanied by two photographs, where Valentino appears in modern clothes and in the typical Argentinian outfit, the profile walks a fine line between immigrant story and narrative of an effortless Americanization. It begins by reminding readers that Valentino had tried his luck as uninspired landscape gardener and as dancing 
partner for the famous Bonnie Glass and Joan Sawyer. But in this account even his setbacks acquire a mantle of heroism. During World War I, as Gassaway recounts, Valentino "was trying frantically to enlist in the Italian service," but his rejection due to a serious eye defect "was a hard blow for the young Italian, son of a cavalry captain and offspring of generations of military leaders." ${ }^{104}$ To further stress his difference from the average Italian immigrant, Gassaway aestheticizes Valentino's real-life appearance as noble, timelessly Italian. His appearance could easily remind one of "little peak-eared marble satyrs you see in Italian gardens" and even though, in preparation for the interview, a studio's makeup artists had thickly covered with pink paint "Rudy's olive complexion" and applied blue-black penciled shadows to further emphasize "the blackness of his eyes," "the finely-chiseled lines of his patrician nose and mouth were au naturel." ${ }^{105}$ In Gassaway's prose, Valentino's racial and national otherness, including his accent, are transmuted into a noble and purely exotic charm.

In his responses to Gassaway's questions, the Italian actor himself took pains to make his diversity appear acceptable by distinguishing it from that of African Americans. He refers to the danger of spending too much time in the sun at the beach since he is "very dark in complexion" and "the sun it burn me too black for pictures. I become like a neegroe [sic]." ${ }^{106}$ Such a demeaning kind of racial distancing proved useful for casting Valentino as an ultimately acceptable Arab-looking lover in The Sheik. Another way in which Gassaway seeks to tame, without erasing, Valentino's otherness is to combine it with several recognizably American traits that Valentino had quickly learned to showcase-including self-control, reserve, and constant physical activity. The sustained references to his new habits and controlled manners makes Gassaway predict that "the stars seem very favorable toward this young, very Americanized foreigner." 107 Ultimately, and in conjunction with shorter reviews and biographical pieces, this profile was the first to suggest that the Four Horsemen's impressive success was due to Valentino's emergent stardom. In 1926 Terry Ramsaye voiced this opinion quite explicitly when he reported that although "the gross earnings up to the end of 1925 on the picture were about $\$ 4,000,000$ [. . . it was not, after all, a triumph of a war picture." Instead, he insisted, "it was a triumph of a new Don Juan of the screen, a victory for Latin love and suppressed desire among the movie millions."

The rhetorical emphasis of these profiles was spontaneity, as if Valentino's stardom was effortless and inevitable. Gassaway's 1921 profile, however, attached a distinct name to the prediction of Valentino's rise to fame-that of Herbert Howe. In praising the Italian actor's talent and describing his bright future, Gassaway felt he was usurping "Howe's prerogative [. . . in predicting that [Valentino] will achieve his most notable successes in manly, bandolined roles." ${ }^{109}$ Howe was an influential contributor to fan periodicals, as well as a publicist, often a secretive one, yet known for his ability to manage stars' public reputations. The frequency of his editorials and range of his collaborations amount to a significant contribution 
to the emergence of Hollywood star discourse. He was possibly one of the first of a list of ballyhoo experts who shaped Valentino's career and reception in America. Like many other early film writers and journalists, he has remained marginalized in traditional film histories.

Information about Howe is limited. Born Herbert Riley Howe in South Dakota in 1893, Howe "began working as a film publicist in New York in the early 1910s," served in the U.S. Tank Corps during World War I, returned to New York as a New York Telegraph reporter and started writing for fan magazines, including Photo-Play Journal, Motion Picture Classic, and Photoplay. ${ }^{110}$ Under contract as a publicist in 1921 with both Brewster Publications and the Vitagraph Company, he was by then a recognized star scout, effective interviewer, and so-called ethnographer of the Hollywood colony's peculiar mores. Due to his sophistication and intellectual preparation, he was known as a "Hollywood boulevardier," which was also the name of his column, first for Motion Picture Classic and later for the New Movie Magazine. He was also a most consummate publicist, unabashedly willing to use his columns and reputation to launch and support stars' career. At the time of the Four Horsemen's success, Howe was writing a popular column for Picture Play Magazine, entitled "Right Off the Grill," which was devoted to "unrestrained comment on picture players, and correspondents." In August 1921, four and a half months after Valentino appeared on screen as Julio, Howe devoted a remarkable profile to the Italian actor not to celebrate his "screen glamour," but to study him "as a subject for success." 111 It was the first of many publicity pieces. Arguably, Howe's overall contribution to Valentino's fame was as significant as Mathis's. The Metro chief screenwriter capitalized on the public interest that Valentino had spurred first as a private citizen and then as a minor actor and translated his appeal into a daring but sympathetic role that brought him an unprecedented level of fame. Howe also took advantage of her creative work and translated Valentino's notable screen performance into an alleged real-life personality that fueled other performances and a lifetime of coverage. ${ }^{112}$

Howe's 1921 profile articulates the acceptability of Valentino's otherness for the film industry-censors and spectators alike. Against the intentions and plans of the "fanatical evangels," Howe notes, Valentino's screen presence "suggests a devil within the law, liable to break through without notice. That's why the ladies are going to like him." By depicting him as a romantic creature from another time, Howe had clear ideas about the new space that Valentino came to occupy in America's film imagery. "Most of us still have a sort of moonshine love for the outlawry," he argues, pointing to Valentino as someone who "suggests romance with a crimson thrill." ${ }_{113}$ Howe predicates the actor's acceptable otherness as a mixture of succesful immigrant narrative-from rags to riches, elitist personal background, and Orientalist racial traits.

While Valentino had migrated to America like millions of immigrants, his alleged social background separated him from them. Because of his personal 
ancestry (a "cavalry officer" for a father and "a lady of gentility and lineage" for a mother), Howe argues, the economic hardship and the solitude initially experienced in New York were harder on him than on other, lower-class migrants. "The peasant of Europe can get work digging in the sewers," Valentino observes. "I had nothing to offer, and even if I had I couldn't tell them about it." What Valentino had, however, were "all the forms of gallantry known to the Continental cavalier." As a result, "Women were enamored of his manner, his beauty, his grace, his low-murmuring Latin tones."114 Still, his humbling experience of landing in New York with the other immigrants was a healthy antidote against arrogance. When success came, Howe remarks, he was not "reshaped by the arch-sycophant, Mademoiselle Fame." Instead he remained grounded and always mindful of "those days in New York when I didn't know where I could get food." Howe's interview does not shy away from the actor's scandalous past ("People thought of me only as a dancer-a lounge lizard") but uses it to attract sympathy for an idol profoundly misunderstood, terribly lonely, but much wiser for all that. And yet national difference ("A jug of wine, a plate of spaghetti, a pack of cigarettes, and Valentino is a success most anywhere") had to be combined with an appealing exoticism. In Howe's article Valentino explains his "wanderlust” in terms of his possibly Orientalist physicality ("His narrow, lotus-lidded eyes are enigmatic. Another reason for the interest of the curious sex. They are the eyes of the Orient") and outlook on life ("The Orient fascinates me. There seems to be some secret wisdom in it"). ${ }^{15}$ Ultimately, the actor emerges from the profile as "an introspective Bedouin, a youthful Omar searching the Mystery, a pagan lover of the spirit," who admirers intimately related to as "Rudie."

Between The Four Horsemen and his next blockbuster, The Sheik, three productions failed to catalyze a comparable fan discourse. For instance, Uncharted Seas (April 1921) and The Conquering Power (July 1921), also produced by Metro, did not contribute to Valentino's stardom as exotic Latin Lover-whether unapologetically daring or contritely sensitive. In the former, he played the role of a courageous ship commander Frank Underwood, active in the Arctic Seas. But as Variety noted, the film's plot appeared "unconvincing and conventional," and all the characters, including his, were "so unnaturally drawn" that it was "impossible to associate them with ordinary human beings." "116 In the latter, he was a wealthy young dandy named Charles Grandet, and his interpretation was singled out as charming for its "youthful appeal, vivacity and cleverness" but nothing more. ${ }^{117}$ The same can be said for Camille (September 1921), an Alla Nazimova vehicle, also produced by Metro, adapted by Mathis from La Dame aux camélias by Alexandre Dumas fils and featuring art direction by Valentino's second wife, film costume and set designer Natacha Rambova. ${ }^{118}$ Valentino played the role of Armand Duval, a young and unsophisticated law student, who falls in love with the Nazimova character, but at no point in the film, which critics labeled artificial and unrelatable, did he appear as other than a victim of passion and circumstances. ${ }^{119}$ 
The publicity leading up to the film placed him in the "supporting company" even though the role in The Four Horsemen had "won him celebrity."120

Unsurprisingly, these films do not figure prominently in the established discourse about Valentino's different masculinity because the fan discourse still looked at his interpretation in The Four Horsemen as his primary role. By the fall of 1921, months after its release, critics and editorialists still described its freshness and originality in terms of the racial and cultural novelty of its leading man, for whom Photoplay eventually abandoned its long-standing front-page policy. "If we ever decide to have men on the covers," the editors wrote in October, "[Valentino] will be the first man." ${ }^{121}$ The plan came to fruition with the February 1922 issue of Photoplay, which sported an image of the Italian actor in attire suitable to the sheik craze. And it is to The Sheik and the publicity the film generated that we should now turn. 